\title{
Concentration and Competition in the Albanian Banking Sector
}

\author{
Msc. Eleana Lici \\ Economic Department, "Eqrem Cabej" University \\ e.lici@acg.edu \\ Msc. Irena Boboli \\ Economic Department, "Eqrem Cabej” University \\ irena_boboli@yahoo.com
}

\begin{abstract}
Albania has a relatively new financial system, where banking system is the most developed financial service in our country, with a share of $94,4 \%$ of the total financial services. This is a phenomenon of countries with emerging economies, which proves that there is greater reliance on the state economic development of the banking sector, by effecting from the households to the biggest investors and the government. As in any market, competition is important for the banking sector because, it affects the efficiency and the quality of services offered. Furthermore, competition in banking has also implications for other sectors of the economy. So, higher competition in the banking sector is found to be associated with a faster growth of other sectors of the economy that rely on external financing. The main goal of this paper is to understand the characteristics of competition in our banking system and study the relationship between the level of concentration and competition. We are going to measure the concentration by the " $H$ " indices. The " $H$ " (Herfindaflit) indices is a measure of the level of the concentration of the banking system of a country. A high level of the indices shows a high level of concentration and as a consequence a low level of competition. A low level of the indices shows a low level of concentration which is sign of a banking market with a high competition.
\end{abstract}

Keywords: Banking System, Market Structure, Bank Concentration, $\mathrm{H}$ index.

\section{Introduction}

The Albanian banking sector has undergone a deep transformation since 1992 and witnessed an impressive growth over recent years. The environment has become very dynamic, especially after the privatization of the Savings Bank. This has been shown in the increase of the range of the products provided by banks, in their geographic expansion, and in the boost of the lending activities. These developments have been associated by a steady decrease in the market concentration, which, however remains the highest compared to other countries in the region. The banking industry remains the largest and the most developed segment of the Albanian financial market. In the Albanian banking sector today are operating 16 banks, with fully private capital and foreign capital dominates. This can be considered as a relatively large number of banks compare with the number of population in Albania, which increases the competition and makes it difficult the cooperation between banks to increase the interest rates. However by comparison with the region we found that in Albania operates a smaller number of banks and higher fees are applied. Also interest rates are higher than in the region, although the differences are not very large. In order to analyze the market structure on banking industry, sometimes we focused on banking concentration. Market concentration is one of the most important determinants of competitiveness (Nathan and Neavel,1989). Competition is important for the banking sector, because as in every other market, it affects the efficiency and the quality of the services offered. Furthermore, competition in banking has also implications for other sectors of the economy. So higher competition in the banking sector is found to be associated with a faster growth of other sectors of the economy that rely on external financing (Claessens and Laeven, 2005). In addition, Deida and Fattouh (2002) found that high concentration in banking is negatively related to industrial growth in low-income countries but not in high-income ones, suggesting that emerging economies need a relatively more competitive banking sector in order to promote growth. For a developing economy like Albania, while a highly competitive banking sector would be desirable to enhance the economic 
growth, at the same time it may also become a source of instability for the financial system. From the comparisons with EU and other countries in the region, the competition level in our banking system seems to be at satisfactory levels for a developing country as Albania.

\section{Concentration in the Banking Industry}

Market concentration is one of the most important determinants of competitiveness. High concentration within a market is typically not a desirable quality. It tends to lead to higher prices, lower outputs and a smaller consumer surplus even in the absence of collusion. Firms in highly concentrated markets often sustain high profits for long periods of time. In many industrialized countries banking is a highly concentrated industry. Because of the potential losses from a breakdown of the banking system, concentration in the industry can be good in a few critical ways. A study done by the National Bureau of Economic Research found that high concentration leads to high stability in the banking industry. They found that a concentration level of $72 \%$ or above was directly correlated to fewer occurrences of banking failure within that nation. There are three principle benefits of high concentration:

1. Banks of large size are easily diversified. This allows them to adjust in other sectors of the market when one sector takes a turn for the worse. A smaller bank that focuses on one or two sectors of the industry is highly vulnerable to fluctuations within those sectors.

2. High concentration levels will increase profits for the dominant banks within the industry. While this may lead to higher interest rates and fees it will also insulate banks from economic shocks. Also, with higher franchise values banks will have less incentive to take financial risks in pursuit of profits (Helen, Murdoch, Stiglitz).

3. Larger banks are more easily monitored than many small banks. It is easier for a regulatory commission to look after a few large banks than many small ones. System within each of the large banks will be similar rather than having to learn the systems of many small banks.

The NBER (National Bureau of Economic Research) paper number 9921 written in 2003 found that there was a significant negative correlation between bank size and banking failures. As the size of banks went up, the amount of banking failures decreased. A one Standard Deviation increase in bank size led to a $1 \%$ decrease in the chance of bank failure. The chance of a bank failure across the entire study was only $4 \%$, so these findings are significant.

Except of the benefits of high concentration there are also some negative effects:

1. As in almost any industry, high concentration will lead to low levels of competition and higher prices, this is no exception. Higher interest rates are often the byproduct of high levels of bank concentration. This is particularly bad for investors as it make investment far more risky.

2. Some niches within the industry are likely not to be filled. The large banks will focus on the most profitable niches and may neglect those that are less profitable. Even taking into account the negative attributes of a highly concentrated banking system, the NBER still found that it led to increased stability. If you think about it, this makes perfect sense. The more market power that a firm has the more likely it is to obtain higher than normal profits. This will undoubtedly lead to greater stability for that firm, this is nothing new.

\section{Measures of Banking Concentration}

The importance of concentration ratios arises from their ability to capture structural features of a market. Concentration ratios are also able to reflect changes in concentration as a result of the bank's entry into the market or its exit from it, or caused by a merge. Despite the several various approaches related to its measurement, the principal elements of concentration measures are number of banks and the distribution of bank size in a given market. Concentration in the banking system is measured through two indicators, the Herfindahl Index (HHI) and CR3 or CR5. Below we are going to explain the performance of these two indicators. 


\section{Herfindahl Index (HHI)}

Herfindahl-Hirschman Index $(\mathrm{HHI})$ is a measure of the size of firms in relation to the industry and an indicator of the amount of competition among them. The name is taken from the economists Orris $\mathrm{C}$. Herfindahl and Albert O.Hirschman. It is an economic concept widely applied in competition law, antitrust and also technology management. This index is defined as the sum of the squares of the market shares of the 50 largest firms (or summed over all the firms if there are fewer than 50) within the industry, where the market shares are expressed as fractions. This index faces two major problems: 1 . Not take into account the extent of replacement of products and services, 2. Face difficulties in defining the geographical market. Herfindahl index is between $1 / n$ and 1 reaching low limits when all subjects are the same size and the upper limits in the case of monopoly. Market used to classify these estimates:

$\mathrm{HHI}$ index bellow 0,01 (or 100) shows a very competitive market

$\mathrm{HHI}$ index less than 0,15 (or 1500) indicates a non-concentrated market

$\mathrm{HHI}$ index between 0,15 to 0,25 (or 1500 and 2500 ) shows a moderate concentration.

$\mathrm{HHI}$ index over $0,25(2500)$ shows that we have a high concentration.

\section{Concentration ratios $\mathrm{CR} 3$ and $\mathrm{CR} 5$}

The concentration ratios are usually used to show the extent of market control of the largest firms in the industry and to illustrate the degree to which an industry is oligopolistic. CR3 and CR5 indices are calculated as the sum of the weight of assets, deposits and loans to total loans, respectively the 3 and 5 largest banks in the banking industry. Concentration ratios range from 0 to 100 percent. The levels reach from no, low, or medium to high "total" concentration.

No concentration - $0 \%$ means perfect competition or at the very least monopolistic competition.

Low concentration - $0 \%$ to $50 \%$, this category ranges from perfect competition to oligopoly.

Medium concentration $-50 \%$ to $80 \%$, an industry in this range is likely an oligopoly.

High concentration $-80 \%$ to $100 \%$, this category ranges from oligopoly to monopoly.

Total concentration $-100 \%$, means an extremely concentrated oligopoly.

The definition of the concentration ratio does not use the market shares of all the firms in the industry and does not provide the distribution of firm size. It also does not provide a lot of details about competitiveness of the industry. The concentration ratios just provide a sign of the oligopolistic nature of an industry and indicate the degree of competition. The Herfindahl index provides a more complete picture of industry concentration than does the concentration ratio.

\section{Market Concentration in Albanian Banking Sector}

In this paper we are going to analyze the empirical results of banking concentration in the Albanian banking market, referring to the concentration ratios, CR3 and CR5 and the Herfindahl- Hirschman Index during the period 2000-2012. Concentration indices are calculated for four components of banking activity: assets, deposits, credits, treasure bills.

\subsection{Market Concentration on Banking Assets}

An important indicator for measuring the concentration level is the CR3 and CR5-Concentration ratio by calculating the weight of 3 or 5 largest banks in the system to total assets of the system. Concentration rates derived from CR3 and CR5 show a high concentration level although their trend has been downward. The Herfindahl-Hirschman Index to total assets showed stable levels in recent years and a great progress towards optimal concentration level, although still far from it. Table 1 presents the empirical results for banking assets during 2000-2012. 
Table 1. Concentration ratios (\%) and $\mathrm{HHI}$ for assets

\begin{tabular}{|l|l|l|l|l|l|l|l|l|l|l|l|l|l|}
\hline Year & $\mathbf{2 0 0 0}$ & $\mathbf{2 0 0 1}$ & $\mathbf{2 0 0 2}$ & $\mathbf{2 0 0 3}$ & $\mathbf{2 0 0 4}$ & $\mathbf{2 0 0 5}$ & $\mathbf{2 0 0 6}$ & $\mathbf{2 0 0 7}$ & $\mathbf{2 0 0 8}$ & $\mathbf{2 0 0 9}$ & $\mathbf{2 0 1 0}$ & $\mathbf{2 0 1 1}$ & $\mathbf{2 0 1 2}$ \\
\hline CR3 & 80 & 75 & 72 & 70 & 69 & 64 & 62 & 56 & 55 & 56 & 56 & 58 & 58 \\
\hline CR5 & 89 & 87 & 86 & 85 & 83 & 78 & 76 & 72 & 74 & 73 & 71 & 73 & 73 \\
\hline HHI & 0.44 & 0.38 & 0.32 & 0.30 & 0.27 & 0.21 & 0.17 & 0.16 & 0.15 & 0.14 & 0.14 & 0.15 & 0.15 \\
\hline
\end{tabular}

Source: Bank of Albania, 2000-2012, own calculations

\subsection{Market concentration on banking deposits}

Concentration rates derived from CR3 and CR5 show a high concentration level although their trend has been declining these years but not stationary. The Albanian banking system shows a high degree of deposit concentration, where the 5 largest banks in the system comprised $74 \%$ of total deposits, at 2012. The estimates of concentration of bank deposits by $\mathrm{HHI}$ points to a high level of concentration until 2006 and for the following period shows a moderate concentration level.

Deposit market remains concentrated compared with the assets market. Although the level of concentration of deposits among the years has fallen the figures are greater than optimal value, which shows a high concentration of market deposits in the banking sector. This may come as a result of a combination of several factors: use of high levels of capital and disengagement of deposits as a source of funds by some banks, preferences of customers, facility in access of customers if we take into account the geographical distribution of bank branches and agencies.

Table 2. Concentration ratios (\%) and $\mathrm{HHI}$ for deposits

\begin{tabular}{|l|l|l|l|l|l|l|l|l|l|l|l|l|l|}
\hline Year & $\mathbf{2 0 0 0}$ & $\mathbf{2 0 0 1}$ & $\mathbf{2 0 0 2}$ & $\mathbf{2 0 0 3}$ & $\mathbf{2 0 0 4}$ & $\mathbf{2 0 0 5}$ & $\mathbf{2 0 0 6}$ & $\mathbf{2 0 0 7}$ & $\mathbf{2 0 0 8}$ & $\mathbf{2 0 0 9}$ & $\mathbf{2 0 1 0}$ & $\mathbf{2 0 1 1}$ & $\mathbf{2 0 1 2}$ \\
\hline CR3 & 84 & 80 & 77 & 75 & 73 & 68 & 64 & 60 & 62 & 60 & 58 & 60 & 59 \\
\hline CR5 & 92 & 90 & 88 & 87 & 85 & 81 & 77 & 75 & 78 & 75 & 74 & 75 & 74 \\
\hline HHI & 0.50 & 0.43 & 0.37 & 0.35 & 0.31 & 0.24 & 0.20 & 0.17 & 0.17 & 0.16 & 0.15 & 0.16 & 0.15 \\
\hline
\end{tabular}

Source: Bank of Albania, 2000-2012, own calculations

\subsection{Market Concentration on Banking Loans}

The lending activity is less concentrated in Albanian banking market. Credit market is characterized by a moderate level of concentration during the years 2002-2012, with $\mathrm{HHI}$ within border $0.1-0.18$, which corresponds to a moderate level of concentration. The Albanian banking market is considered to be highly concentrated in terms of assets and deposits, and moderately concentrated, close to perfect competition in terms of lending.

Table 3. Concentration ratios (\%) and $\mathrm{HHI}$ for loans

\begin{tabular}{|l|l|l|l|l|l|l|l|l|l|l|l|l|l|}
\hline Year & $\mathbf{2 0 0 0}$ & $\mathbf{2 0 0 1}$ & $\mathbf{2 0 0 2}$ & $\mathbf{2 0 0 3}$ & $\mathbf{2 0 0 4}$ & $\mathbf{2 0 0 5}$ & $\mathbf{2 0 0 6}$ & $\mathbf{2 0 0 7}$ & $\mathbf{2 0 0 8}$ & $\mathbf{2 0 0 9}$ & $\mathbf{2 0 1 0}$ & $\mathbf{2 0 1 1}$ & $\mathbf{2 0 1 2}$ \\
\hline CR3 & 78 & 69 & 62 & 54 & 46 & 43 & 43 & 41 & 41 & 42 & 43 & 47 & 50 \\
\hline CR5 & 91 & 86 & 83 & 79 & 69 & 63 & 66 & 66 & 67 & 65 & 64 & 68 & 68 \\
\hline HHI & 0.27 & 0.20 & 0.14 & 0.15 & 0.11 & 0.10 & 0.11 & 0.11 & 0.12 & 0.11 & 0.11 & 0.12 & 0.12 \\
\hline
\end{tabular}

Source: Bank of Albania, 2000-2012, own calculations

\subsection{Market Concentration on T- Bills}

In Albania Tirana Stock Exchange doesn't exist and is still one of the main challenges of the financial system. There are no shares listed in the stock market and an official stock market doesn't exist. The only securities that are trading are Tbills and in absence of stock exchange T- bills are traded from Bank of Albania. Thus T-bills activity evaluates as indicator of competition. Market structure of T-bills in Albanian banking sector was monopoly and was accompanied by very high concentrations ratios. The estimates of concentration of bank T-bills by HHI points to a high level of concentration until 2008 and for the following period shows a moderate concentration level. These results are due to the dominant position held by Raiffeisen Bank in Treasury bond market. 
Table 3. Concentration ratios (\%) and HHI for T-bills

\begin{tabular}{|l|l|l|l|l|l|l|l|l|l|l|l|l|l|}
\hline Year & $\mathbf{2 0 0 0}$ & $\mathbf{2 0 0 1}$ & $\mathbf{2 0 0 2}$ & $\mathbf{2 0 0 3}$ & $\mathbf{2 0 0 4}$ & $\mathbf{2 0 0 5}$ & $\mathbf{2 0 0 6}$ & $\mathbf{2 0 0 7}$ & $\mathbf{2 0 0 8}$ & $\mathbf{2 0 0 9}$ & $\mathbf{2 0 1 0}$ & $\mathbf{2 0 1 1}$ & $\mathbf{2 0 1 2}$ \\
\hline CR3 & $\mathrm{Na}$ & 82 & 91 & 89 & 86 & 80 & 71 & 62 & 68 & 64 & 59 & 58 & 57 \\
\hline CR5 & $\mathrm{Na}$ & 91 & 96 & 95 & 95 & 88 & 80 & 76 & 84 & 81 & 76 & 76 & 78 \\
\hline HHI & 0.72 & 0.67 & 0.62 & 0.59 & 0.53 & 0.42 & 0.33 & 0.24 & 0.22 & 0.17 & 0.16 & 0.17 & 0.15 \\
\hline
\end{tabular}

Source: Own calculations

\section{Conclusions}

Herfindahl Index calculated on the Albanian market for total assets, deposits, loans and T-bills has been steadily decreasing. According to this indicator T-bills are more concentrated.

The indicators $\mathrm{CR} 3$ and $\mathrm{CR} 5$ for loans have an increasing tendency, while these indicators have shown a slight tendency for assets, deposits and T-bills to increase.

Three largest banks that have the greatest share in the deposit and loans are: Raiffeisen Bank, National Commercial Bank and Intesa Sanpaolo, with a predominance of Raiffeisen Bank.

This study finds a strong evidence of change to the market structure in Albanian banking sector, which has been recently characterized by important structural developments. The most important of them are:

- The enlarged number of banks

- $\quad$ Restructuring and privatization of state- owned banks

- Establishment of domestic capital banks

- Entrance of powerful foreign banks through acquisitions of the existing ones which have changed the Albanian banking sector into a dynamic environment.

\section{References}

[1] Bank of Albania (2008) Annual Report; pg 20-58

[2] Bank of Albania (2010) Annual Report; pg 70

[3] Bank of Albania (2012) Annual Report; pg 25

[4] Berger, A. N., Demirgüç -Kunt, A., and Levine R. and Joseph G. Haubrich, (2004), Bank Concentration and Competition: An Evolution in the Making, Journal of Money, Credit and Banking, Vol. 36, No.3, pp.434-450.

[5] Bikker J. A. and HAAF, K. (2001b), Competition ,Concentration and Their Relationship: An empirical Analysis of the Banking Industry, De Nederlandsche Bank (DNB) Staff Reports, No. 68

[6] Bikker, J. A, and Haaf, K. (2000), Measures of Competition and Concentration, a review of the literature, De Nederlandsche Bank, Directorate Supervision, 2)):563-583.

[7] Gruda, S., Hashorva, A. (2002), Privatization of Albanian Saving Bank and Competition between Banks. The Case of Albanian Banking System, AESCU Conference, May, 2009

[8] Hashorva, A., Tushaj, A., Borici, A. (2009), The Effect of Market Inherited Structure on Competition between Banks. The case of Albanian Banking System, AESCU Conference, May, 2009.

[9] Jansen, D. and DeHaan, J. (2003), Increasing concentration in European banking: A macro-level analysis, De Nederlandsche Bank, Research Memorandum WO, No. 743, September.

[10] Duka, R., Hashorva, A. (1997), Bad Loans and Non Performing Loans: case of the banking system in Albania; Paper presented at the Conference on "The restructuring and privatisation of banks, bad loans portfolios, and their impact on enterprise restructuring in early transition" December, 1997, Tirana. 
[11] Cetorelli, N. (2004), Bank Concentration and Competition in Europe, Journal of Money, Credit, and Banking.

[12] Cetorelli, N., Hirtle, B., Morgan, D., Peristiani, S., Santos, J. (2007), Trends in Financial Market Concentration and Their Implications for Market Stability. Federal Reserve Bank of New York Policy Review, 33-51.

[13] Claessens, S., and Laeven, L. (2004), What Drives Bank Competition? Some International Evidence. Journal of Money Credit and Banking 36 (3 (2)):563- 583. 